\title{
Household dynamics and small timber consumption in rural Kashmir (J\&K), India
}

\author{
M. Y. Baba*, M. A. Islam and P. A. Sofi \\ Faculty of Forestry, Sher-e-Kashmir University of Agricultural Sciences \& Technology of Kashmir, Benhama, \\ Ganderbal-191201 (J \& K), INDIA \\ *Corresponding author. E-mail:babayaseen2@gmail.com \\ Received: December 4, 2015; Revised received: August 27, 2016; Accepted: November 5, 2016
}

\begin{abstract}
The study examined the extraction and consumption pattern of small timber and its socioeconomic and forest resource determinants among the rural people in district Ganderbal of Kashmir. The results showed that the total extraction of small timber from different sources in the sample villages was 39.46 tons annum ${ }^{-1}$, which is mostly consumed in housing and roofing (39.63\%) followed by cattle shed/ store house $(15.25 \%)$, rural furniture/ packing cases $(14.75 \%)$, agricultural implements $(13.25 \%)$, fencing $(12.50 \%)$ and others $(4.62 \%)$. The total small timber demand was $47.88 \mathrm{~m}^{3}$ annum ${ }^{-1}$, which is mostly procured from agroforestry $(42.57 \%)$ followed by forests $(26.09 \%)$, homestead forestry $(17.05 \%)$ and social/ community forestry $(14.29 \%)$. The people were destitute with respect to socioeconomic attributes while they are well-off regarding forest resource characteristics. Correlation and multiple regression analysis established a robust relationship between small timber consumption and socioeconomic and forest resource parameters. The small timber flow from forests to the sample villages is excessive as compared to the national estimates, creating threats to the biodiversity conservation and ecological stability of the adjoining forests. The over-utilization of forest biomass by the local people is leading to degradation of forest resources and diminished biomass productivity, which in turn induce socioeconomic and livelihood stress. Therefore, some alternative interventions are essential to be implemented efficiently to keep pace with current development and future challenges.
\end{abstract}

Keywords: Consumption, Extraction, Forest resource, Kashmir, Small timber, Socioeconomic

\section{INTRODUCTION}

Timber is a renewable, sustainable, attractive, strong, durable and cost effective natural building material that combines beauty, superior performance and environmental advantage (Binkley, 2005). Its flexibility and versatility offer a multitude of structural applications such as beams, walls, flooring, cladding, containers, packing cases, formwork, large timber panels, agricultural implements, fencing, hutments, housing, furniture, scaffolding, mine props etc. (Islam et al., $2015 \mathrm{~b}$ ). The timber used in fencing of agricultural lands, hutments, most of rural housing, scaffolding, mine props and most of agricultural implements is small timber while for many other uses it is large timber (Rai and Chakrabarti, 1996). The demand for small timber is met through supplies from government forests and non-forest sources such as farmlands and homestead gardens (Chandra et al., 2008). In India, the demand of timber was 92 million $\mathrm{m}^{3}$ i.e., $0.098 \mathrm{~m}^{3}$ or $3.5 \mathrm{cft}$ per capita per year. The situation regarding timber (at current productivity) is not grave but moratorium on fellings and market demands creates pressure. The paradox is that forests produce 70 percent timber and 30 percent fuel wood, while the demand for wood is around 70 percent as fuel wood and 30 percent as timber (Rai and Chakrabarti, 2001). This really exacerbates the situation. The forests have at least 5 times more pressure on them for fuel wood and small timber than what they can withstand, as a matter of sustained productivity. Forests represent a key component of available national and regional biomass supply in rural India. Exploitation of forest biomass is a common way for small timber security among forest fringe dwellers (Khanduri et al., 2002). Primarily in the rural India and also in the urban sectors, most of the population depends on forests directly to meet the bulk of small timber requirement. About 275 million (World Bank, 2006) to 350- 400 million (MoEF, 2009) people living in forest fringe villages depend upon forests for a variety of goods and services like materials for agricultural implements, house construction and fencing etc. in India. The total annual consumption of wood in constructions and furniture, both in commercial and household sector as well as for agricultural implements are estimated to be 48.0 million cubic meters in Round Wood Equivalent in India. However, the total production of timber stands at 45.95 million cubic meters, showing a gap of 2.05 million cubic meters annually (FSI, 2013). Of the total production of $45.95 \mathrm{~m}$ cum, the production of timber from forests are estimated to be $3.175 \mathrm{~m}$ cum whereas the annual potential produc- 
tion of timber from trees outside forest (TOF) is estimated to be $42.774 \mathrm{~m}^{3}$ (Yadav and Basera, 2013).

The extraction and consumption situation of small timber in rural sectors plays an important role in the socioeconomic, cultural, farming and geo-environmental conditions of a region (Dangwal, 2005). The dependency of rural households in the forest resources for small timber procurement and their diverse use pattern has become an important topical issue in developing economies. Increasing trade in small timber has supported economic growth and has helped in reducing poverty in a number of emerging countries. There is strong evidence that small timber play a significant role in the livelihoods of the world's rural poor (Chandramolly and Islam, 2015). Collection and sale of small timber are the main source of income for the forest dwelling population in many countries (Yadav and Basera, 2013). Small timber is an integral component in rural societies of Kashmir which is extracted from forests, traditional agroforestry, community forestry and homestead forestry and consumed for packing cases, agricultural implements, furniture, housing, sports goods, cart and carriages building, cattle sheds, store houses, fencing, scaffolding, ladder and cremation (Gangoo et al., 2015). The subject has become increasingly concerned with prominent roles of socioeconomic and forest resource characteristics on extraction and consumption patterns of small timber among rural communities. Since, a clear description to understand various socioeconomic and forest resource factors influencing extraction and consumption patterns of small timber is imperative the topic has assumed greater importance and received priority for small timber development and management for holistic conservation initiatives (Islam et al., 2015a). This sort of understanding is necessarily region specific and is missing in Kashmir context, the present study is an attempt to document the status of extraction and consumption of small timber and how it is influenced by the household socioeconomic and forest resource characteristics in the rural societies of Kashmir.

\section{MATERIALS AND METHODS}

Study area: The study was conducted in district Ganderbal situated at $34^{\circ} 14^{\prime} 0^{\prime \prime} \mathrm{N}$ and $74^{\circ} 47^{\prime} 0^{\prime \prime} \mathrm{E}$ at an altitude of 1,619 $\mathrm{m}$ above MSL in Kashmir. Total geographical area of the district is 39304 ha which is differentiated as; forest (10949 ha), non-agricultural use (5758 ha), barren and un-cultivable land (3161 ha), permanent pastures and other grazing land (1790 ha), cultivable waste land (973 ha) and net area sown (16673 ha) (irrigated, 10962 ha and un-irrigated, 5711 ha). The district has total human population of 297446 (158,720 male and 138,726 female) which is about $2.38 \%$ of total population of J\&K (Anonymous, 2011), the literacy rate of $59.98 \%$ (male $68.85 \%$ and female $45.71 \%$ ), sex ratio of 874 female per 1000 males, fami- ly size of 6.62 and population density of $1148 \mathrm{~km}^{-2}$. The district comprises of $84.19 \%$ of rural and $15.81 \%$ of urban population living in 136 villages and 44831 households (Census of India, 2011).

Sampling technique: Multi-stage random sampling technique (Ray and Mondol, 2004) was employed to select the sample villages and the respondents for the field study. In the first stage, fourteen sample villages viz., Babosipora, Bandi Bagh, Gund Rahman, Dev Pora, Darend, Daraduder, Tangchatir, Gund Ari, Drag Tanga, Narayan Bagh, Badam Pora, Ahan, Danger Pora and Bagh Mahanand out of 136 revenue villages having around 10 percent sampling intensity in the district have been selected. A sample of 114 households having 10 percent of the total number of the households was drawn from the sample villages in the second stage. Household heads or eldest members were treated as respondents.

Data collection: Data on extraction and consumption of small timber and its socioeconomic-cum-forest resource characteristics among the rural households were gathered by personal interviews administering a well structured pre-tested interview schedule and nonparticipant observations (Mukherjee, 1993). The estimates of small timbers extraction and consumption were made by requesting the respondents to record the dimensions (lengths and diameters) of the small timbers they extract and consume day-to-day. The volumes of the small timbers extracted and consumed by the households were calculated using Smallian's formula (Dangwal, 2005) as follows:

$$
\mathrm{V}=\frac{\left(\mathrm{S}_{\mathrm{b}}+\mathrm{S}_{\mathrm{t}}\right)}{2} \times \mathrm{L}
$$

where, $S_{b}$ and $S_{t}$ are the basal area of the butt and top end of the bole, $\mathrm{L}$ is the length and $\mathrm{V}$ is the volume of the bole.

The total small timber extraction and consumption per annum in the sample households, contribution of different sources in timber procurement, use of timber for various purposes and average annual household small timber extraction and consumption were later estimated. The socioeconomic and forest resource variables were measured (Table 1) using the scale of Venkataramaiah (1990) and Singha et al. (2006).

Data analysis: Suitable statistical tools like mean $(\mathrm{x})$, frequency (f), percentage $(\%)$, correlation (r) and multiple regressions (b) were used for analysis of the data (Snedecor and Cochran, 1967). The multiple regression statistics was used to determine the effect of socioeconomic and forest resource characteristics on consumption of small timber. The fundamental prediction equation was as follows:

$\mathrm{Y}=\mathrm{a}+\mathrm{b}_{1} \mathrm{x}_{1}+\mathrm{b}_{2} \mathrm{x}_{2}+\ldots \ldots \ldots \ldots+\mathrm{b}_{\mathrm{n}} \mathrm{x}_{\mathrm{n}}+\mathrm{E}_{\mathrm{n}}$ where, $\mathrm{Y}=$ small timber consumption (tons household ${ }^{-1}$ annum $\left.^{-1}\right), \quad \mathrm{a}=$ intercept,$x_{1}-x_{n}=$ values of independent variables, $b_{1}-b_{n}=$ regression coeffcients, $n=$ number of independent variables, $E n=$ Error term 


\section{RESULTS AND DISCUSSION}

Socioeconomic and forest resource characteristics: The descriptive statistics for socioeconomic and forest resources characteristics of the sample households (Table 2) indicated that there was prevalence of middle aged (46.85) respondents having literacy up to secondary level (3.68), no membership or membership of only one organization $(0.81)$ and belonged to large family size and nuclear (3.12) family type. The size of land holding among most of the respondents (1.08) were marginal, engaged mainly in cultivation or business (3.46), having 6 to 10 livestock (1.98), one pucca house (4.95), medium wealth status (23.10) and gross annual income up to Rs. 60000/ annum (2.82). Majority of the respondents were having proximity of 5 to 10 $\mathrm{km}$ to the forests who visits the forests frequently (1.77) and access the forest plantation most often (2.38). The extent of agroforestry/ homestead forestry among most of the respondents $(87.72 \%)$ was up to 0.30 ha and the urban closeness varied between 5 to $10 \mathrm{~km}$.

The results showed that despite inhabiting in resource rich areas, the rural people are in underprivileged conditions with respect to their socioeconomic characteristics, hence, the socioeconomic conditions of the people is away from the expected level and as such, there is still much scope to improve their quality of life. Nonetheless, the people are in prosperous position with regard to forest resource characteristics, which needs to be exploited efficiently to meet the basic needs in terms of fuel, fodder, timber and other NTFPs and livelihood diversification based on the existing forest resources needs to be implemented as important strategy of socioeconomic upliftment of the local people. Small timber extraction and consumption: The average small timber requirement was worked out to be $0.42 \mathrm{~m}^{3}$ household $^{-1}$ annum ${ }^{-1}$, accounting for a total small timber demand of $47.88 \mathrm{~m}^{3}$ annum ${ }^{-1}$. The agroforestry alone contributed 42.57 percent of the total small timber requirement followed by forests (26.09\%), homestead forestry $(17.05 \%)$ and social/ community forestry (14.29\%) (Table 3$)$. The total extraction of small timber is about $39.46 \mathrm{~m}^{3}$ annum ${ }^{-1} @ 0.35$ household $^{-1}$ annum ${ }^{-1}$. The small timber extracted is mostly consumed in housing and roofing (39.63\%) followed by cattle shed/ store house $(15.25 \%)$, rural furniture/ packing cases $(14.75 \%)$, agricultural implements $(13.25 \%)$, fencing $(12.50 \%)$ and others such as scaffolding/ ladder/ underground cold storage, sports goods, cremation etc. $(4.62 \%)$ in the surveyed population (Table 3$)$.

The agroforests and forests jointly contributed 68.66 percent of the total small timber requirement while the remaining 31.34 percent of the small timber requirement is fulfilled by social/ community forestry and homestead forestry. Agroforestry plantations are a rural way of life in Kashmir valley since time immemorial (Islam et al., 2015a). The woody and fruit tree species most commonly grown under agroforestry plantations to meet household need of the small timbers are Salix alba, Populus deltoides, Robinia pseudoacacia, Populus nigra, Morus alba, Juglans regia, Ulmus wal-

Table 1. Description of the socioeconomic and forest resource variables.

\begin{tabular}{|c|c|}
\hline Variable & Description \\
\hline Age $\left(X_{1}\right)$ & Chronological age in year \\
\hline Education $\left(\mathrm{X}_{2}\right)$ & $\begin{array}{l}0=\text { illiterate }, 1=\text { below primary, } 2=\text { primary, } 3=\text { middle, } 4=\text { high school, } 5=\text { intermediate }, \\
6=\text { graduate } \& \text { above }\end{array}$ \\
\hline Social participation $\left(\mathrm{X}_{3}\right)$ & $\begin{array}{l}0=\text { no participation, } 1=\text { membership of } 1 \text { organization, } 2=\text { membership of }>1 \text { organization, } \\
3=\text { office bearer, } 4=\text { public leader }\end{array}$ \\
\hline Family composition $\left(\mathrm{X}_{4}\right)$ & Family type: $1=$ nuclear, $2=$ joint; Family size: $1=$ upto 5 members, $2=>5$ members \\
\hline Size of land holding $\left(\mathrm{X}_{5}\right)$ & $\begin{array}{l}0=\text { landless, } 1=\text { marginal }(\text { upto } 1.0 \mathrm{ha}), 2=\text { small }(1.1 \text { to } 2.0 \mathrm{ha}), 3=\text { medium }(2.1 \text { to } 4.0 \mathrm{ha}), \\
4=\text { large }(>4.0 \mathrm{ha})\end{array}$ \\
\hline Livestock possession $\left(\mathrm{X}_{6}\right)$ & $0=$ no livestock, $1=$ upto 5 livestock, $2=6$ to 10 livestock, $3=$ more than 10 livestock \\
\hline Housing stat & $\begin{array}{l}\text { Type: } 0=\text { no house, } 1=\text { hut, } 2=\text { temporary structure, } 3=\text { mixed, } 4=\text { permanent structure; } \\
\text { Number of rooms: } 1=01,2=02,3=>02\end{array}$ \\
\hline Main occupation $\left(\mathrm{X}_{8}\right)$ & $\begin{array}{l}1=\text { wage labour, } 2=\text { caste occupation, } 3=\text { cultivation, } 4=\text { business, } 5=\text { service, } 6=\text { any } \\
\text { other }\end{array}$ \\
\hline Gross annual income $\left(\mathrm{X}_{9}\right)$ & Rs./ annum \\
\hline Wealth status $\left(\mathrm{X}_{10}\right)$ & $\begin{array}{l}1=\text { smokeless crude oven, } 1=\text { stove, } 1=\text { sewing machine, } 1=\text { watch, } 1=\text { cycle, } 1=\text { radio, } 1= \\
\text { wooden furniture, } 1=\text { pressure cooker, } 2=\text { improved storage bin, } 2=\text { tape recorder, } 3= \\
\text { scooter } / \text { motor cycle, } 1=\text { any other }\end{array}$ \\
\hline Proximity to forests $\left(\mathrm{X}_{11}\right)$ & Distance of forests from household $(\mathrm{km})$ \\
\hline $\begin{array}{l}\text { Frequency of forest visits } \\
\left(\mathrm{X}_{12}\right)\end{array}$ & Very frequently $=3$, frequently $=2$, occasionally $=1$ and never $=0$ \\
\hline $\begin{array}{l}\text { Extent of agroforestry/ home- } \\
\text { stead plantation }\left(\mathrm{X}_{13}\right)\end{array}$ & Land area occupied under agroforestry/ homestead forestry plantation (ha) \\
\hline $\begin{array}{l}\text { Access to the forest plantation } \\
\left(\mathrm{X}_{14}\right)\end{array}$ & How often the household members access to the nearby forests plantations (no.) \\
\hline Urban closeness $\mathrm{s}\left(\mathrm{X}_{15}\right)$ & How far an individual household in the village is from the city or town $(\mathrm{km})$. \\
\hline
\end{tabular}


M.Y. Baba et al. / J. Appl. \& Nat. Sci. 8 (4): 2021-2028 (2016)

Table 2. Descriptive statistics for socioeconomic and forest resourse parameters $(\mathrm{N}=114)$.

\begin{tabular}{lllllll}
\hline Characteristic & Mean & $\begin{array}{l}\text { Std. } \\
\text { Dev. }\end{array}$ & $\begin{array}{l}\text { 95\% Confidence interval for } \\
\text { mean }\end{array}$ & Minimum & Maximum \\
\hline & & & Lower bound & Upper bound & \\
\hline Age $\left(\mathrm{X}_{1}\right)$ & 46.85 & 11.52 & 44.71 & 48.99 & 22 & 69 \\
Education $\left(\mathrm{X}_{2}\right)$ & 3.68 & 1.47 & 3.40 & 3.95 & 0 & 6 \\
Social participation $\left(\mathrm{X}_{3}\right)$ & 0.81 & 1.07 & 0.61 & 1.01 & 0 & 4 \\
Family composition $\left(\mathrm{X}_{4}\right)$ & 3.12 & 0.77 & 2.98 & 3.26 & 2 & 4 \\
Size of land holding $\left(\mathrm{X}_{5}\right)$ & 1.08 & 0.42 & 1.00 & 1.16 & 0 & 3 \\
Livestock possession $\left(\mathrm{X}_{6}\right)$ & 1.98 & 0.89 & 1.81 & 2.15 & 0 & 3 \\
Housing status $\left(\mathrm{X}_{7}\right)$ & 4.95 & 0.79 & 4.80 & 5.09 & 3 & 6 \\
Main occupation $\left(\mathrm{X}_{8}\right)$ & 3.46 & 1.29 & 3.22 & 3.70 & 1 & 6 \\
Gross annual income $\left(\mathrm{X}_{9}\right)$ & 2.82 & 0.79 & 2.67 & 2.96 & 1 & 4 \\
Wealth status $\left(\mathrm{X}_{10}\right)$ & 23.10 & 7.20 & 21.76 & 24.43 & 10 & 38 \\
Proximity to forests $\left(\mathrm{X}_{11}\right)$ & 9.30 & 5.39 & 8.30 & 10.30 & 2.50 & 18 \\
Frequency of forest visits $\left(\mathrm{X}_{12}\right)$ & 1.77 & 1.06 & 1.58 & 1.97 & 0 & 3 \\
Extent of agroforestry/ homestead & 0.22 & 0.15 & 0.19 & 0.25 & 0 & 1 \\
plantation $\left(\mathrm{X}_{13}\right)$ & & & & & & 3 \\
Access to the forest plantation $\left(\mathrm{X}_{14}\right)$ & 2.38 & 0.85 & 2.22 & 2.53 & 0 & 3 \\
Urban closeness $\left(\mathrm{X}_{15}\right)$ & 9.78 & 4.00 & 9.04 & 10.53 & 2.00 & 17.50 \\
\hline
\end{tabular}

Table 3. Small timber extraction and consumption in the sample households $(\mathrm{N}=114)$.

\begin{tabular}{|c|c|c|c|c|c|}
\hline \multirow{2}{*}{$\begin{array}{l}\text { Extraction } \\
\text { Source }\end{array}$} & \multicolumn{4}{|c|}{ Consumption } & \multirow[b]{2}{*}{ Percentage } \\
\hline & 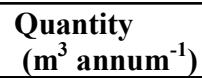 & Percentage & Purpose & $\begin{array}{l}\text { Quantity } \\
\left(\mathrm{m}^{3} \text { annum }^{-1}\right)\end{array}$ & \\
\hline Forests & 10.29 & 26.09 & Housing/ roofing & 18.98 & 39.63 \\
\hline Agroforestry & 16.80 & 42.57 & Agricultural implements & 06.34 & 13.25 \\
\hline $\begin{array}{l}\text { Social/ Community } \\
\text { forestry }\end{array}$ & 05.64 & 14.29 & Rural furniture/ packing cases & 07.06 & 14.75 \\
\hline Homestead forestry & 06.73 & 17.05 & Fencing & 05.99 & 12.50 \\
\hline - & - & - & Cattle shed/ store house & 07.30 & 15.25 \\
\hline- & - & - & $\begin{array}{l}\text { Others (Scaffolding/ ladder/ under- } \\
\text { ground cold storage/ sports goods etc.) }\end{array}$ & 02.21 & 4.62 \\
\hline Total & 39.46 & $100 \%$ & Total & 47.88 & $100 \%$ \\
\hline $\mathrm{X}+$ S.E. & $0.35+0.01$ & - & - & $0.42+0.02$ & - \\
\hline
\end{tabular}

Table 4. Correlation and multiple regression analysis of independent variables with the small timber consumption $(\mathrm{N}=114)$.

\begin{tabular}{|c|c|c|c|c|}
\hline Independent variable (Code) & $\begin{array}{ll}\text { Co-efficient } & \text { of } \\
\text { correlation (r) }\end{array}$ & Regression coefficient (b) & $\begin{array}{l}\text { Standard } \\
\text { error of ' } b \text { ' }\end{array}$ & $\begin{array}{l}\text { 't' } \\
\text { value }\end{array}$ \\
\hline Age $\left(X_{1}\right)$ & 0.176 & 0.000 & 0.001 & -0.568 \\
\hline Education $\left(\mathrm{X}_{2}\right)$ & $0.383 *$ & 0.001 & 0.006 & 0.166 \\
\hline Social participation $\left(\mathrm{X}_{3}\right)$ & $0.704 *$ & 0.028 & 0.009 & $2.979 *$ \\
\hline Family composition $\left(\mathrm{X}_{4}\right)$ & $0.541^{*}$ & 0.015 & 0.013 & 1.191 \\
\hline Size of land holding $\left(\mathrm{X}_{5}\right)$ & $0.691 *$ & 0.118 & 0.022 & $5.271 *$ \\
\hline Livestock possession $\left(\mathrm{X}_{6}\right)$ & $0.639 *$ & 0.014 & 0.013 & 1.075 \\
\hline Housing status $\left(\mathrm{X}_{7}\right)$ & $0.494 *$ & 0.026 & 0.011 & $2.283 *$ \\
\hline Main occupation $\left(\mathrm{X}_{8}\right)$ & $0.408^{*}$ & 0.001 & 0.007 & 0.210 \\
\hline Gross annual income $\left(\mathrm{X}_{9}\right)$ & $0.517 *$ & 0.019 & 0.012 & 1.619 \\
\hline Wealth status $\left(\mathrm{X}_{10}\right)$ & $0.343 *$ & 0.000 & 0.001 & 0.309 \\
\hline Proximity to forests $\left(\mathrm{X}_{11}\right)$ & $0.502 *$ & 0.003 & 0.002 & 1.383 \\
\hline Frequency of forest visits $\left(\mathrm{X}_{12}\right)$ & $0.524 *$ & 0.018 & 0.009 & $2.004 *$ \\
\hline $\begin{array}{l}\text { Extent of agroforestry/ homestead plantation } \\
\left(\mathrm{X}_{13}\right)\end{array}$ & $0.671^{*}$ & 0.275 & 0.061 & $4.499 *$ \\
\hline Access to the forest plantation $\left(\mathrm{X}_{14}\right)$ & $0.573^{*}$ & -0.002 & 0.012 & -0.181 \\
\hline Urban closeness s $\left(\mathrm{X}_{15}\right)$ & $-0.584^{*}$ & -0.007 & 0.002 & -3.443 \\
\hline
\end{tabular}

$\mathrm{a}=-0.022 ; \mathrm{F}=35.138 * ; \mathrm{R}^{2}=0.843 ;$ Multiple $\mathrm{R}=0.918 ;$ Adjusted $\mathrm{R}^{2}=0.819 ; *$ Significant at 5

lichiana, Ailanthus excelsa, Malus domestica, Pyrus communis, Prunus persica, Prunus armeniaca, Palatanus orientalis etc. (Mushtaq et al., 2015). There is a considerable pressure on forests for meeting the timber requirement of the local people. The poverty, low literacy and awareness, substandard socioeconomic conditions, traditional severity, easy accessibility of forests among the local people and availability of inadequate 
markets, communication and transportation facilities hinder them to access substitute of timber for their household consumption. The construction of katcha, mixed or pucca houses and repair, making agricultural implements such as ploughs, harrows, rollers, clodcrushers, tool handles etc., manufacture of low cost rural furniture such as chairs, stools, desks, tables, benches, boxes, beds, shelves, lockers etc. packing cases, hutments and sports goods etc. are the main sectors where major fraction of the small timber is consumed. The requirement of small timber for other purposes such as carts and carriages making, fencing of agricultural fields and homesteads, preparation of cattle shed/ store house and making scaffolding, ladder etc. and cremation is comparatively low. A number of workers (Sapkota and Oden, 2008; Sarmah and Arunachalam, 2011; Mushtaq et al., 2012; Sati and Song, 2012; Islam et al., 2015b) have reported the enormous pressure on agroforest and forest biomass for timber security among rural communities.

Correlation analysis: Among the socioeconomic and forest resource variables the education, social participation, family composition, size of land holding, livestock possession, housing status, main occupation, gross annual income, wealth status, proximity to forests, frequency of forest visits, extent of agroforestry/ homestead forestry plantation and access to the forest plantation were exhibited positively significant correlation with the consumption of small timber. The urban closeness had a negatively significant correlation with the small timber consumption whereas; the age of the respondents had shown a non-significant correlation. The positively significant correlation between education and consumption of small timber is well articulated by the facts that the education results in bringing desirable changes in human behavior and helps the individual to move in right direction (Egeru et al., 2010), the knowledge is built up through education, which makes the person aware of new innovations (Sood et al., 2008), and the change in attitude is partly a function of education (Singha et al., 2006). The social participation of the rural people paves the way for sharing their views and experiences with other members of the organization (Nagesha and Gangadharappa, 2006), clarifying their doubts and getting opinion from different people and enriching their knowledge (Thamban et al., 2008). This is how the significant influence of this variable on consumption of small timber can be explained. The positive and significant relationship of family composition with the consumption of small timber could be due to the fact that the independent decision making regarding any matter concerning to small timber is easy in the nuclear family as compared to joint family (Ajake and Enang, 2012) and the larger sized families were having more labor force available for more extraction of small timber (Larinde and Olasupo, 2011). The involvement of local people of different age groups in extraction of small timber was more or less similar indicating that the variations in age has no influence on the extraction and consumption of small timber at all.

The co-efficient of correlation ( $r$ ) of all the six economic variables namely, size of land holding, livestock possession, housing status, main occupation, gross annual income, wealth status with the consumption of small timber were recorded to be positive and significant. The persons who have big size of land holding will have good economic condition (Egeru et al., 2010) and more scope for availability of small timber by encompassing appropriate combinations of farm enterprises (Prakash and Sharma, 2008). This might be the probable reason to have positive and significant association between size of land holding and the consumption of small timber. The main occupation of the local people exhibited direct bearing on the earning of money (Chaudhary and Panjabi, 2005; Kumaresan and Devi, 2009), facilitating the possession of small timber among the local people that's why the higher the occupational pattern the higher will be extraction and consumption of small timber. The other economic attributes viz., housing status, livestock possession and wealth status are the major indicators of physical capital possessed by the local people (Chaudhary et al., 2004) and the physical capital is a core contributor and the representative of the small timber possessions (Pandey and Mishra, 2011). These assets play an important role in their economy (Pal, 2011) and help them to facilitate the other types of capitals to be owned and traded (Kumar and Siddaramaiah, 1996). The gross annual incomes of the local people are the prominent indicator of financial capital possessed (Sharma et al., 2012) and the financial capital occupies central position governing the small timber possession (Srivastava, 2006). The persons thus, who have higher gross annual income will also have higher small timber consumption. All the forest resource characteristics viz., proximity to forests, frequency of forest visits, extent of agroforestry/ homestead forestry plantation and access to the forest plantations have direct influence on extraction and consumption pattern of small timber, thus, the higher the custody of these variables the higher will be extraction and consumption of small timber. That's why these variables had exhibited positive and significant correlation with the consumption of small timber. The negatively significant association of urban closeness with the consumption of small timber could be articulated to the fact that the urban people have some other alternatives of these forest resources lessening their dependency on these resources. Multiple regression analysis: The multiple regression analysis was performed to describe the relative contribution of independent variables of the people on the small timber consumption (Table 4). The co-efficient of determination $\left(\mathrm{R}^{2}\right)$ worked out to be 0.843 which 
signified that all the independent variables of the people put together had contributed to $84.30 \%$ variation on the small timber consumption. The analysis of ' $t$ ' values of regression co-efficient indicated that out of the fifteen independent variables, social participation, size of land holding, frequency of forest visits and extent of agroforestry/ homestead plantation had significant contribution in influencing the consumption of small timber. Thus, the social participation, size of land holding, frequency of forest visits and extent of agroforestry/ homestead plantation turned out to be the potential predictors in explaining the variation in the consumption of small timber. The social participation of the rural people paves the way for sharing their views and experiences with other members of the organization (Ponnusamy and Gupta, 2006; Bedia, 2014), clarifying their doubts and getting opinion from different people and enriching their knowledge (Prakash and Sharma, 2008). This is how the significant influence of this variable on consumption of small timber can be explained. The size of land holding have direct influences on procurement of small timber needs, the household with larger size of land holding can arrange large quantity of small timber while the families having smaller size of land holding mitigate little quantity of small timber. The housing status is the major indicator of physical capital possessed (Nagesha and Gangadharappa, 2006) indicating the socioeconomic status of the family (Prakash and Sharma, 2008) and facilitating the other types of capitals to be owned and traded (Ponnusamy and Gupta, 2006). The frequency of forest visits and extent of agroforestry/ homestead plantation are the crucial variables having direct impact on mitigation of small timber needs. The families with higher custodian of these variables could arrange maximum amount of small timber whereas, families devoid of these variables were facing scarcity of small timber. The findings are in consistent with the Singha et al. (2006) who observed that the household independent variables play prominent roles on extraction and consumption of small timber and participation in maintenance practices of forest resources in rural communities of Assam. The multiple regression models for small timber consumption fitted to be given as: $\mathrm{Y}_{3}=-0.022+0.000 \mathrm{X}_{1}+0.001 \mathrm{X}_{2}+0.028 \mathrm{X}_{3}+0.015 \mathrm{X}_{4}$ $+0.118 \mathrm{X}_{5}+0.014 \mathrm{X}_{6}+0.026 \mathrm{X}_{7}+0.001 \mathrm{X}_{8}+0.019 \mathrm{X}_{9}$ $+0.000 \mathrm{X}_{10}+0.003 \mathrm{X}_{11}+0.018 \mathrm{X}_{12}+0.275 \mathrm{X}_{13}-$ $0.002 \mathrm{X}_{14}-0.007 \mathrm{X}_{15}$

Where, $\mathrm{Y}_{3}=$ Small timber consumption (tons household $^{-1}$ annum $^{-1}$ )

$\mathrm{X}_{1}-\mathrm{X}_{15}=$ Independent variables

The $F$ value (35.14) showed that the analysis was significant at $5 \%$ level of probability and all the fifteen variables contributed significantly in the variation of the small timber consumption of the rural people. The result is confirmed by Singha et al. (2006) who reported that the household independent variables are the significant contributors of the small timber consumption in rural communities of Assam.

\section{Conclusion}

This study investigated the socioeconomic and forest recourses drivers affecting the extraction and consumption of small timber among the rural people in Kashmir. Results indicated that the socioeconomic condition of the people is far away from the desired level while they are prosperous with regard to their forest resource characteristics. Total extraction of small timber from different sources in the sample villages was 39.46 tons annum $^{-1} @ 0.35$ household $^{-1}$ annum $^{-1}$. The small timber flow from forests to the sample villages is excessive (10.29 tons annum $\left.{ }^{-1}\right)$ creating threats to the biodiversity conservation, diminished biomass productivity and ecological stability, which in turn encourage socioeconomic and livelihood stress. Multivariate analysis $\left(\mathrm{R}^{2}=0.843\right)$ showed that all the fifteen variables contributed significantly in the small timber extraction and consumption. To check the overutilization of forest biomass and keep pace with current small timber needs and future challenges, there is an urgent need to implement some alternative interventions efficiently. Further, the socioeconomic and forest resource characteristics which influenced the extraction and consumption of small timber significantly should be given due importance during decision making, planning and implementation of developmental strategies to relieve the pressure of small timber on forests in the locality.

\section{ACKNOWLEDGEMENTS}

The authors sincerely acknowledge the cooperation and helps extended by the Sarpanchs, Mukhiyas, local leaders, Government officials, NGO workers and villagers in carrying out the research work in the sample villages in District Ganderbal of Kashmir.

\section{REFERENCES}

Ajake, A.O. and Enang, E.E. (2012). Demographic and socio -economic attributes affecting forest ecosystem exploitation and management in the rural communities of cross river state, Nigeria. American International Journal of Contemporary Research, 2(1): 174-184

Anonymous (2011). Directorate of economics and statistics, district statistics and evaluation office, Ganderbal, J\&K, India.

Bedia, S. (2014). Study on the forest based livelihood for the selected tribal population of Ranchi district of Jharkhand. B.Sc. Dissertation, Unpublished. Faculty Centre for Integrated Rural \& Tribal Development and Management, School of Agriculture and Rural Development, Ranchi, Jharkhand, India.

Binkley, C. (2005). A global emerging markets forestry investment strategy, Washington D.C: Suit 900.

Census of India (2011). A - 5 State Primary Census Abstract -2011, India. 
Chandra, R., Soni, P. and Yadav, V. (2008). Fuel wood, fodder and livestock in Himalayan watershed in Mussoorie hills, Uttarakhand, India. The Indian Forester, 135(10): 894-905

Chandramolly and Islam, M.A. (2015). Fuel wood, fodder and timber consumption status in a forest fringe tribal society of Jharkhand, India. International Journal of Forestry and Crop Improvement, 6(1): 71-76

Chaudhary, M.C. and Panjabi, N.K. (2005). Adoption behaviour of tribal and non-tribal farmers regarding improved Social Forestry Practices. Rural India, 67(6): 140-141

Chaudhary, M.C., Panjabi, N.K. and Bhimawat, B.S. (2004). Factors responsible for adoption of Social Forestry programme in tribal areas of Rajasthan. Rural India, 66(4): 65-68

Dangwal, D.D. (2005). Commercialization of forests, timber extraction and deforestation in Uttaranchal. Conservation and Society, 3(1): $110-133$

Egeru, A., Majaliwa, J.G.M., Isubukalu, P.S., Mukwaya, P. and Katerega, E. (2010). The determinants of fuelwood demand: A case of Olio sub-county eastern Uganda. In: Second RUFORUM Biennial Meeting, pp. 1593-1598

FSI (2013). India State of Forest Report. Forest Survey of India, Ministry of Environment and Forests, Government of India, New Delhi, pp. 286

Gangoo, S.A., Masoodi, T.H., Murtaza, Shah and M.A. Islam. (2015). Management of exotic poplars for production of quality timber and reducing cotton menace in Kashmir. The Indian Forester, 141(5): 514-519

Islam, M.A., Masoodi, T.H., Gangoo, S.A., Sofi, P.A., Bhat, G.M., Wani, A.A., Gatoo, A.A., Singh, A. and A.R. Malik. (2015a). Perceptions, attitudes and preferences in agroforestry among Rural Societies of Kashmir, India. Journal of Applied and Natural Science, 7(2): 976983

Islam, M.A., Quli, S.M.S., Rai, R., Ali, Angrej and Gangoo, S.A. (2015b). Forest biomass flow for fuel wood, fodder and timber security among tribal communities of Jharkhand. Journal of Environmental Biology, 36(1): 221228

Khanduri, V.P., Sharma, C.M., Ghildiyal, S.K. and Puspwan, K.S. (2002). Forest composition in relation to socioeconomic status of people at three altitudinal villages of a part of Garhwal Himalayas. The Indian Forester, 128 (12): 1335-1345

Kumar, G.T.P. and Siddaramaiah, B.S. (1996). Influence of socio-psychological characteristics of participant farmers on their knowledge about Joint Forest Planning and Management. My Forest, 32(4): 259-63

Kumaresan, P. and Devi, R.G.G. (2009). Factors discriminating the adoption of separate silkworm rearing houses in south India. Indian Journal of Sericulture, 48(1): 49-55

Larinde, S.L. and Olasupo, O. (2011). Socio-economic importance of fuel wood production in Gambari forest reserve area, Nigeria. Agriculture and Social Research, 11(1): 201-210

MoEF (2009). Asia-Pacific Forestry Sector Outlook Study II: India Country Report. Ministry of Environment and Forests, Working Paper No. APFSOS II/WP/2009/06, FAO, Bangkok: pp. 78

Mukherjee, N. (1993). Participatory Rural Appraisal. Methodology and Applications, Concept Publishing Company, Delhi.
Mushtaq, T., Sood, K.K. and Peshin, R. (2015). Delineating key determinants of domestic fuel wood consumption of rural households in western Himalaya- policy implications. J. Mt. Sci., 11(1): 195-204

Mushtaq, T., Sood, K.K. and Raina, N.S. (2012). Species preferences for fuel wood in Shiwalik Himalayas- implications for agroforestry plantations. Indian Journal of Hill Farming, 25(2): 18-21.

Nagesha, G. and Gangadharappa, N.B. (2006). Adoption of agroforestry systems in north eastern districts of Karnataka. My Forest, 42(4): 337-347

Pal, G. (2011). Socio-economic characteristics of lac growers in Kanker district of Chhattisgarh. The Indian Forester, 137(11): 1294-1297

Pandey, R. and Mishra, A. (2011). Livestock fodder requirements and household characteristics in rural economy of hilly region, Uttarakhand. Himalayan Ecology, 34(4): 35-40

Ponnusamy, K. and Gupta, J. (2006). Factors influencing sustainable livelihood parameters in different farming systems. Asian Journal of Extension Education, 25 (1\&2): 5-9

Prakash, O. and Sharma, R. (2008). Determining people's participation in forest fire control: a study of Himachal Pradesh. Indian Journal of Forestry, 31(1): 1-6

Rai, S.N. and Chakrabarti, S.K. (2001). Demand and supply of fuel wood and timber in India. The Indian Forester, 127(3): 23-29

Rai, S.N. and Chakrabarti, S.K. (1996). Demand and supply of fuel wood, timber and fodder in India. Forest Survey of India, Ministry of Environment and Forests, Dehradun, pp. 36

Ray, G.L. and Mondol, S. (2004). Research Methods in Social Sciences and Extension Education, Kalyani Publishers, New Delhi, 66-76

Sapkota, I.P. and Odén, P.C. (2008). Household characteristics and dependency on community forests in Terai of Nepal. International Journal of Social Forestry, 1(2): 123-144

Sarmah, R. and Arunachalam, A. (2011). Contribution of non-timber forest products (NTFPs) to livelihood economy of people living in forest fringes in Changlang district of Arunachal Pradesh, India. Ind. J. Fund. Appl. Life Sci., 1(2): 157-169

Sati, V.P. and Song, C. (2012). Estimation of forest biomass flow in the montane mainland of the Uttarakhand Himalaya. International Journal of Forest, Soil and Erosion, 2(1): 1-7

Sharma, J., Gairola, S. Gaur, R.D. and Painuli, R.M. (2012). Forest utilization patterns and socio-economic status of the Van Gujjar tribe in sub-Himalayan tracts of Uttarakhand, India. Forestry Studies in China, 14(1): 36-46.

Singha, A.K., Talukdar, R.K. and Singha, J.K. (2006). Maintenance behaviour of forest resources by the people of forest villagers in Assam. Indian Journal of Forestry, 29(1): 47-54

Snedecor, G.W. and Cochran, W.G. (1967). Statistical methods. Iowa State University Press, Ames, Iowa-50010

Sood, K.K., Najiar, C., Singh, K.A., Handique, P., Singh, B. and Rethy, P. (2008). Association between socioeconomic parameters and agroforestry uptake: evidences from eastern Himalaya. Indian Journal of Forestry, 31(4): 559-564 
M.Y. Baba et al. / J. Appl. \& Nat. Sci. 8 (4): 2021-2028 (2016)

Srivastava, S. (2006). Dependence of local people and issues in conserving local resources: case of Dalma wildlife sanctuary, Jharkhand. Indian Forester, 132(1): 31-42

Thamban, C., Vasanthakumar, J., Arulraj, S., Mathew, A.C. and Muralidharan, K. (2008). Farmer's participation in the field implementation of micro-irrigation systems. Journal of Plantation Crops, 36(3): 522-525

Venkataramaiah, P. (1990). Development of socio-economic status scale, Ph.D. Thesis, Department of Agricultural Extension, UAS, Bangalore

World Bank (2006). India: Unlocking Opportunities for Forest Dependent People in India. Report No. 34481 IN, World Bank: South Asia Region, pp. 85

Yadav, M. and Basera, K. (2013). Status of Forest Products Production and Trade Working paper - Centre for SFM \& FC, IIFM Bhopal, pp. 1-14 